\title{
The Competitive and Development Strategy of China's Local Fast Fashion Apparel Enterprises under New Retail Model
}

\author{
Mao-Jun Gong ${ }^{1} \quad$ Jing Wang ${ }^{2 *}$
}

\begin{abstract}
China's apparel industry has developed greatly and became the world's largest apparel production and processing base. With its price advantage, popular style, offline stores and online purchase convenience, fast fashion appealed growing consumers of different ages and areas. In recent years, China's fast fashion clothing has developed rapidly and the market has gradually grown through increases in Cross-border E-commerce activities. SheIn, a Chinese fast fashion apparel enterprise, neither targeted its home country nor sold well there. Instead, the fast fashion online retailer primarily targeted its overseas markets and earned billions of dollars in sales. This research takes the cross-border fast fashion brand SheIn, as an example, to explore the future competitive and development strategy of China's local fast fashion apparel enterprises under new retail model. Our results suggest that paying more attention to domestic markets, increasing the stability of APPs, improving the quality of products, and choosing suitable Cross-border E-commerce platforms may be the competitiveness-increase strategies for SheIn in the future.
\end{abstract}

Keywords: SheIn, Fast Fashion Apparel Enterprises, Cross-border E-commerce

\section{Introduction}

The spread of COVID-19 has influenced the global market dynamics. The impact of COVID-19 on economic development is a typical external impact, not only disordered the economic operation and industry development but exerted a sharp decline in consumer demand. The service-oriented tertiary industry relying on the movement of people and interactive consumption, such as cultural tourism, transportation, catering services, leisure and entertainment, education and training suffered the greatest direct losses. In recent years, the entire China's garment industry has developed in a sluggish state due to factors such as slowing economic growth, supply-side reform, Sino-US trade friction and capacity transfer. Under the influence of COVID-19, the textile and garment industry's production, domestic sales, exports, and other aspects have been seriously affected. Insufficient production, falling offline retail sales and weak overseas demand led to a sharp decline in new orders.

In recent years, China's apparel industry has burgeoning development, which promoted the China economy. In 2005, the total output value of textiles and garments accounted for about one-tenth of China's total output value, and has ranked first in foreign exchange earning surplus for five consecutive years ( $\mathrm{Li}, 2013)$. At the same time, China has become the world's largest apparel production and processing base. For every three garments in the world, one of them comes from China. The apparel industry always boosts China's export earnings.

\footnotetext{
${ }^{1}$ School of International Business, Xiamen University Tan Kah Kee College

${ }^{2}$ Lecturer of School of International Business, Xiamen University Tan Kah Kee College, wangjing@, xujc.com*corresponding author
} 
Since 2016, however, the profit margins of Chinese apparel enterprises have been severely compressed, and the growth rate of performance indicators in the apparel industry has shown a clear downward trend (Figure 1). From January to December 2019, there were 13,876 enterprises above the designated size (annual main business income of 20 million yuan and above) in the apparel industry accounting for cumulative operating income of $1,601.03$ billion-yuan, annual decreasing rate of $3.45 \%$, total profits of 87.28 billion-yuan, and annual decreasing rate of $9.75 \%$. Total output and annual growth rate drop sharply since 2016 with an annual growth rate of $-22.62 \%$ in 2018 (Figure 2). Due to the change in the public's clothing consumption concept, the development of the clothing industry, and the entry of foreign fast fashion clothing brands, Chinese local clothing enterprises have begun to deploy fast fashion clothing.

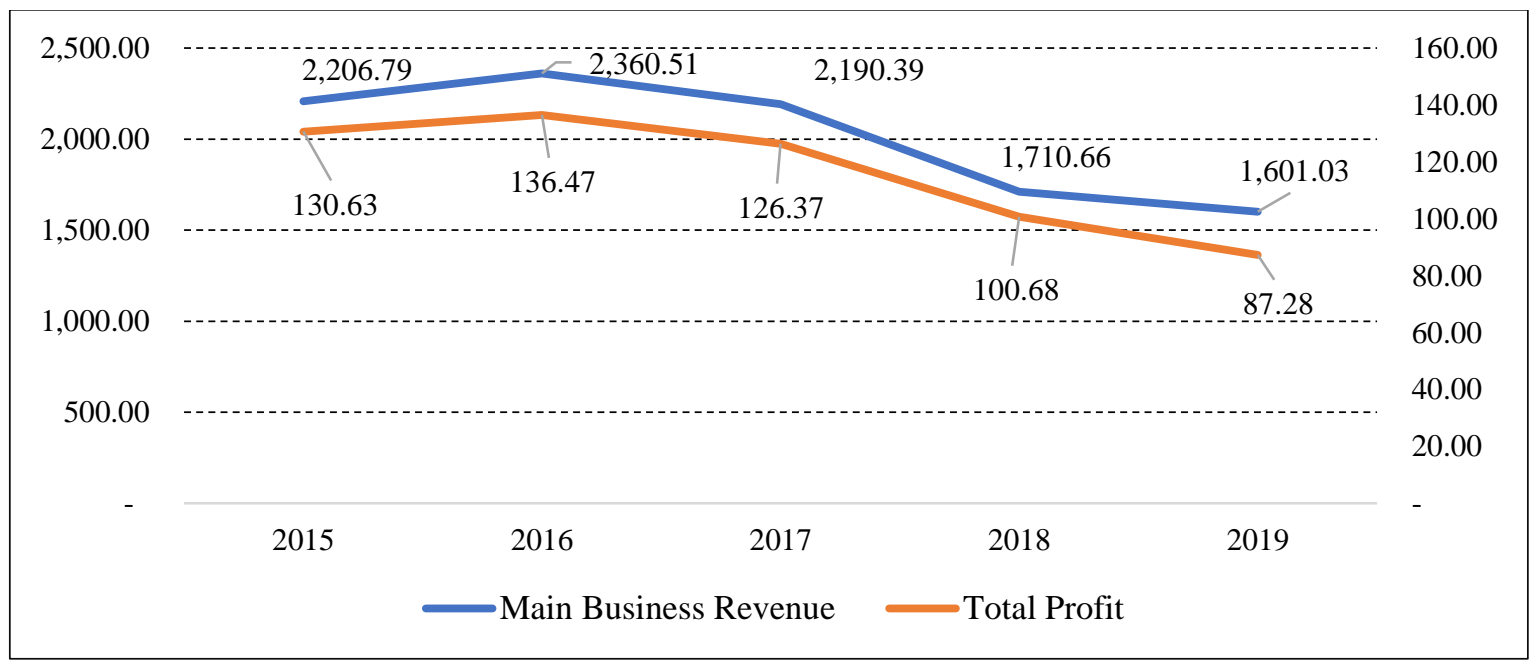

Sources: "Analysis report on market outlook and investment strategic planning of China's clothing retail Industry" in Prospective Industry Research Institute, 2020

Figure 1. 2015-2019 China's above-scale garment enterprises' mainbusiness revenue and total profit (billion RMB)

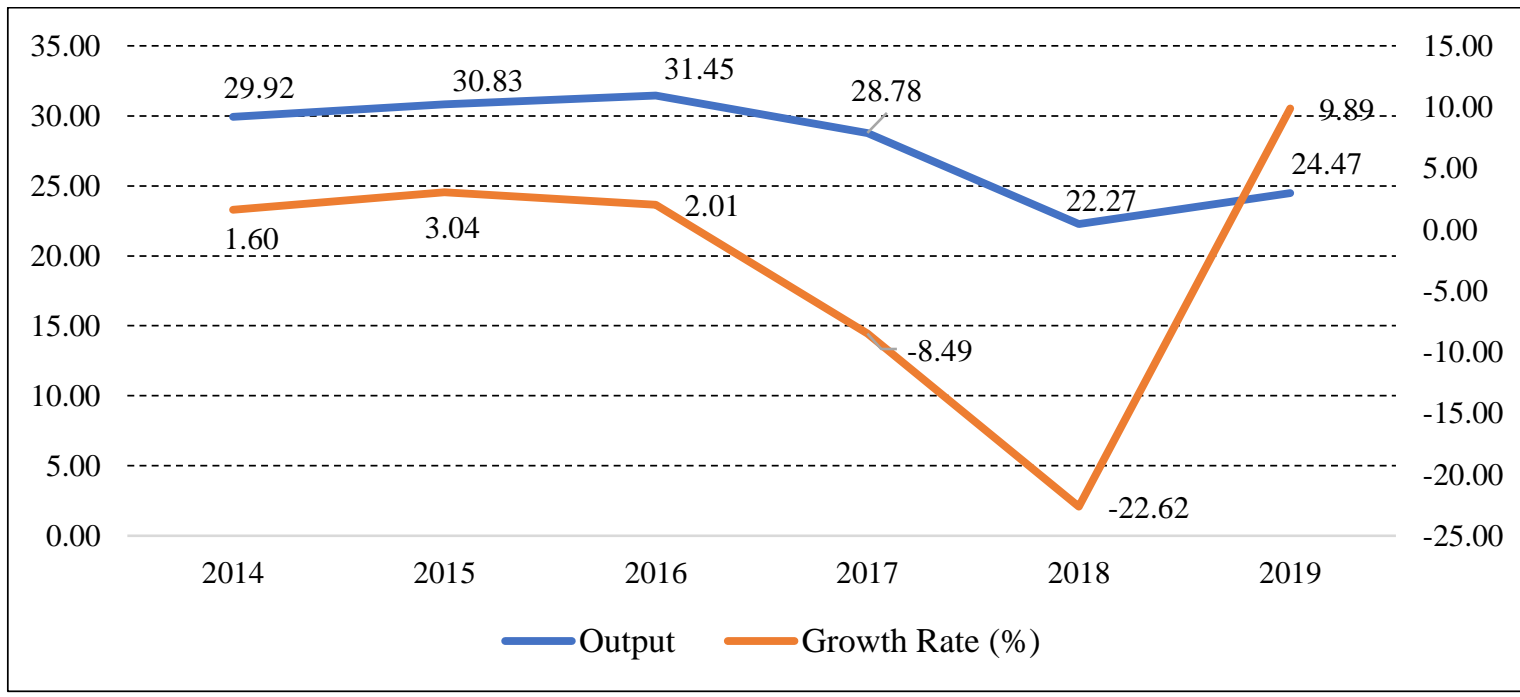

Sources: "Analysis report on market outlook and investment strategic planning of China's clothing retail Industry" in Prospective Industry Research Institute, 2020

Figure 2. 2014-2019 China's above-scale garment enterprises' output and growth rate (billion RMB) 
In China's clothing market, fast fashion clothing attracted young consumer groups with its trendy ideal and fashion life style. With the price advantage, popular style, offline stores and online purchase convenience, fast fashion appealed growing consumers of different ages.

There is no doubt that internet has made people's life become easier and more convenient. Clothing and apparel products as the first major category of online shopping, the overall size of the clothing E-commerce market has been growing in recent years. In 2019, the size of the clothing E-commerce market reached 1,013.37 billion yuan along with $70.4 \%$ of China's consumers had online clothing experience and $76.9 \%$ of consumers bought clothing through online channels. In 2020, over 2 billion e-shoppers would be transacting 13.5 percent of their overall retail consumption online, equivalent to a market value of US\$3.4 trillion (Figure 3). Cross-border E-commerce, as a new trade mode, has changed the traditional form of trade and created a great impact on China's garment industry. China's garment industry had certain advantages in price and quality that might possibly provide more opportunities for small and medium-sized enterprises.

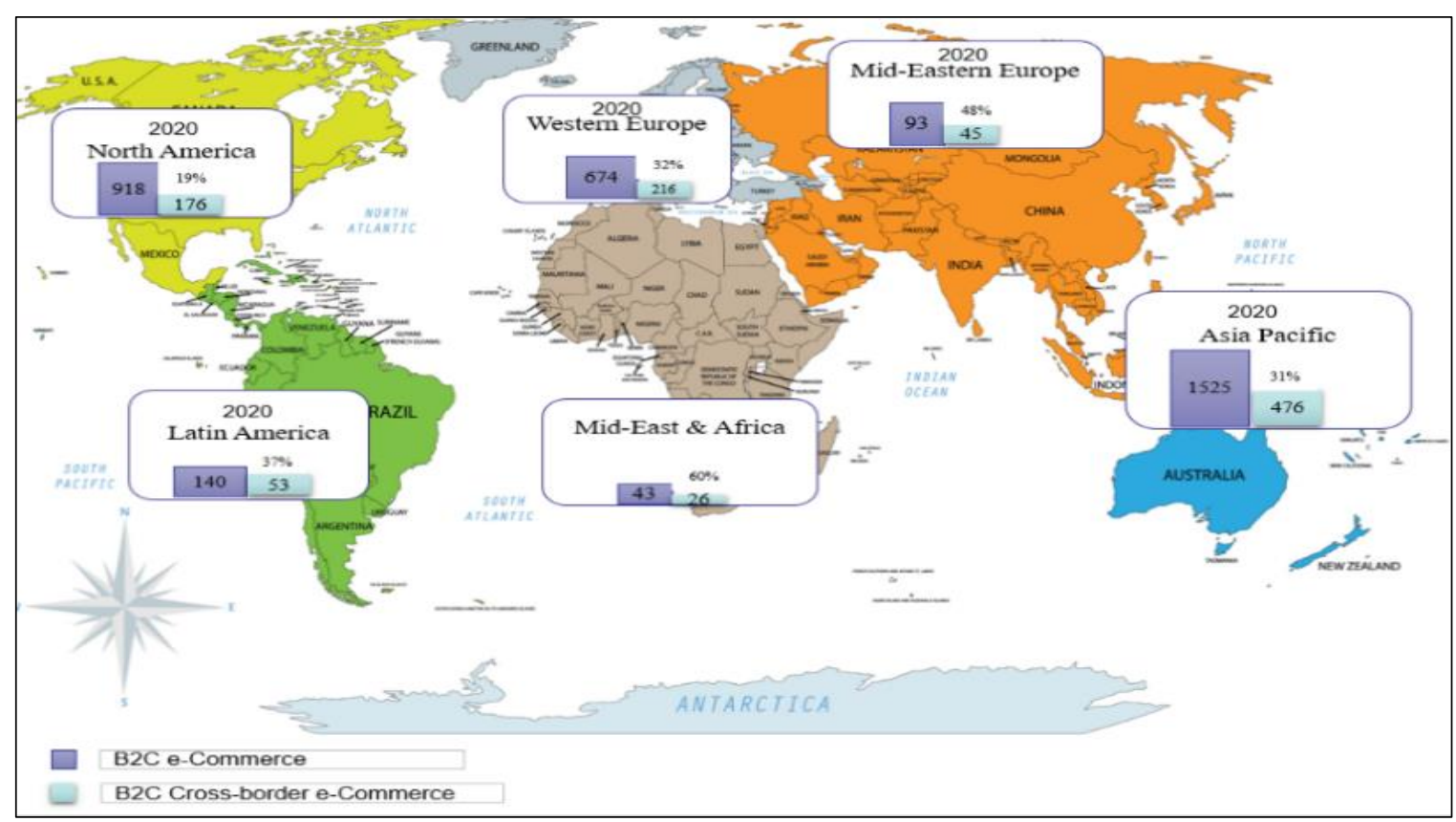

Sources: Forward Business Information Co. (2020)

Figure 3. Global Cross-border B2C E-commerce transaction value (billion US\$)

Benefit from the rapid development of China's E-commerce industry, the overall size of China's clothing E-commerce market in 2015-2018 was increasing annually. In 2018, China's clothing E-commerce market size reached 820.54 billion yuan, an annual increasing rate of $22.0 \%$. It was estimated that the market size of China's clothing E-commerce in 2019 reached 1,013.37 billion yuan (Forward Business Information Co., 2020).

In 2019, purchase price of China's consumer clothing was mainly concentrated in 500 yuan and below. In the price range of lower than 200 yuan and 301-500 yuan, Chinese consumers were more inclined to buy online. The proportion of consumers purchased on these two price ranges was $29 \%$ and $28.6 \%$, respectively, and were both slightly higher than the proportion of offline consumers (Forward Business Information Co., 2020). In the 201300 yuan price range, consumers preferred to buy offline and the proportion of offline consumers was $27.3 \%, 4.2 \%$ higher than the proportion of online consumers. 
SheIn was one of the China's leading online stores boasting high quality clothes and other fashionable accessories since 2008. Her objective was to be the largest online wardrobe company around the world and to offer customers a variety of the latest and most fashionable clothing. As a new type of trade, Cross-border E-commerce has changed the traditional trade and has had a significant impact on the Chinese apparel industry. It also provided more opportunities for small and medium-sized enterprises because of the advantages in quality and variety. This research takes the cross-border fast fashion brand SheIn, as an example, to explore the future competitive and development strategy of China's local fast fashion apparel enterprises under new retail model.

\section{Fast Fashion Apparel Enterprises under Cross-border E-commerce 2.1 China's Local Fast Fashion Apparel Enterprises}

In China's clothing market, fast fashion clothing attracted young consumer groups with its fashion sense and trend of rapid change characteristics. Its price advantages, popular styles, offline stores combined with online purchase convenience appealed increasing consumers of different ages to join the consumer group.

Fast fashion clothing originated in continental Europe. It started from capturing fashion shows to imitating fashion trend design, made ready-to-wear into store sales, and then quickly reached the hands of consumers. With the development of China's economy, foreign fast fashion clothing enterprises merged into Chinese market resulting in the development of China's domestic fast fashion clothing enterprises. In Chinese market, however, foreign fast fashion clothing enterprises remained competitive.

The fast-fashion apparel industry in China has expanded rapidly from 2017 and experienced slow or declining earnings growth after 2018 until the closure of offline stores. At the same time, consumers who bought clothing in the shopping malls often found almost identical clothing styles in several stores. It might be possible choosing a suitable style but uncomfortable fabric materials. Dislocation of supply and demand required China's local fast fashion apparel enterprises to think deeper about the strategic positioning of future enterprises, to combine with the external environment and their own internal conditions, to formulate enterprise strategies for leading the design of enterprises, to from marketing, production, logistics, manpower and other aspects of the work to establish and develop core competitiveness, and to increase the economic efficiency of enterprises.

\subsection{External Environment and Corporate Strategy of China's Local Fast Fashion Apparel Enterprises}

Corporate strategy required the enterprise to set long-term goals and plans first. In order to achieve this goal, the enterprise had to develop what needed to be done, what human resources should be used, in what appropriate place and time to do, and how to implement a series of strategies. At the beginning of formulating the enterprise strategy, the first thing to do was to analyze the external environment in which the enterprise was located. Only by understanding the current situation of the external environment then can they predict the future trend of the industry and formulate the enterprise strategy adapted to the macro environment.

Johnson \& Scholes (1999) have proposed the PEST model for analyzing macroeconomic environment. Although the macro factors differed from industries to enterprises, they were related to the influence factors of the four major categories of politics, economy, society, and technology on the external macro environments. Among them, the political environment factors mainly considered the political system, policies, laws and regulations; economic environmental factors mainly included the international and domestic 
economic situation, the level of economic development and other factors; social environmental factors needed to take into account social structure, moral style, cultural traditions, education and values and other factors; while the technical environmental factors referred to the overall level of social technology and technological breakthroughs on the impact of enterprises.

In terms of technological environmental factors, for example, local fast fashion apparel enterprises needed to pay special attention to the rapid development trend of E-commerce with the popularization of communication Internet technology and mobile terminals. In recent years, the Chinese fast fashion apparel market began to explore new retail business models, that is, enterprises went through online streaming, accessed to customer sources, and customers online ordered, offline experienced services to achieve integration. Online stores usually develop from offline store to approaches of live video, social influencer marketing, integration of big data technology, and other marketing strategies.

Porter's five forces analysis is an industry analysis model for developing corporate strategies to become or remain competitive in an industry. It helps a company exploit opportunities and overcome threats in the external environment of the business. According to Porter, there are five forces that affect the competitive environment of an industry, including rivalry among competitors, threat of new players, bargaining power of consumers, bargaining power of suppliers, and threat of substitute products.

Porter also proposed three basic strategies for companies: First, the overall cost leadership-by improving efficiency, scale, and experience to reduce costs, to obtain cost advantages. Second, the differentiation strategy-by providing a service to maintain the differentiation and additional value, which may cause the potential risk and a partial increase in total costs for manufacturers. Third, the target aggregation strategy-the implementation of a specific market segment, customer base and products of a single enterprise strategy. The core idea of these three strategies is to make enterprises differ in cost, product, or customer market and to achieve economic benefits.

The five-force model can be used to analyze the competitive challenges faced by China' domestic fast fashion apparel companies:

\subsubsection{Rivalry among Competitors}

Foreign fast fashion brand clothing enterprises, such as ZARA of Spain, Uniqlo of Japan, and H.M. of Sweden have taken a leading position in China's fast fashion clothing market. These foreign large-scale fast fashion brand enterprises were very competitive in design, marketing, rapid production and market speed, and product diversity. If China's local fast fashion clothing enterprises wanted to expand their position in the current market share, they needed to establish core competitiveness, enhance market share, and increase economic efficiency.

\subsubsection{Threat of New Players}

The ease with which potential new players enter the industry depended on barriers to the entry. If there were strong barriers to entry into the industry, fewer new competitors will join the market. Barriers to entry included economies of scale, capital requirements, sales channels, and other cost factors that were not related to the size of the business.

With the increase of China's consumer market and residents' income, there will be more foreign fast fashion and light luxury brand clothing enterprises entering Chinese market. As far as China was concerned, more enterprises that used to process exportoriented clothing will also be transformed into independent design to build their own corporate brands into the domestic market. The number of fast fashion clothing enterprises 
will possibly increase in the future.

\subsubsection{Bargaining Power of Consumers}

With the continuous improvement of living standards and consumption upgrading, customers will not only pay more attention to the use and price of clothing, but also to aesthetics and comfort. In particular, the young consumer group was the most important component of the fast fashion category clothing customer group. How to dress up with fashion and personality was the focus of attention of the customer community. While the texture of clothing and wearing comfort were also important choice elements of clothing.

Customers dominated choice of products in many fast fashion clothing enterprises. Because of the development of Internet E-commerce that reduced customer's searching costs, customers can easily transfer and choose different brands of clothing products which indirectly provides the customers a strong bargaining power. However, once a customer preferred certain brand of clothing because of satisfactory purchasing experiences and became a fan of the brand, and/or even this certain brand became a representative of the trend in the public reputation, then the customer's stickiness to the brand increased and the customer's bargaining power weakened. It was therefore essential to build China's local fast fashion clothing brand.

\subsubsection{Bargaining Power of Suppliers}

China's garment processing enterprises did OEM processing services in export clothing market for a long time with many garment processing suppliers. If the local fast fashion garment enterprises chose to outsource processing and production, the number of processing garment factories to be chosen increased and the bargaining power of external processing supplier was relatively weak. However, with the increasing labor costs in China, either outsourcing or own producing garment processing enterprises will face increases in costs of raw materials and labor.

International leading fast fashion apparel companies usually owned a global supply chain system. They can choose countries with lower raw material prices and lower labor costs to limit costs. China's local garment enterprises can transfer production and supply chain to some provinces and cities with better logistics system and lower labor costs, create new production enterprises, or organize new foundry/processing suppliers. These measures can reduce the cost of enterprises, contribute to poverty alleviation in poor areas, and reflect social responsibility of enterprises.

\subsubsection{Threat of Substitute Products}

Compared with other clothing enterprises, the core comparative advantage of fast fashion apparel industry was "fast" with unparalleled advantages in its vertical integration supply chain model. However, if other clothing enterprises added a strong sense of novel design, customers were likely to transfer the purchases which created a competitive pressure for alternatives to fast fashion clothing.

With the influence of modern network on daily life, E-commerce greatly stimulated consumer's purchasing desire. Clothing and apparel products as the first major category of online shopping, the overall size of the clothing E-commerce market in recent years has been increasing. As a new trade mode, Cross-border E-commerce has changed the traditional trade form, which has had a great impact on China's garment industry and provided more opportunities for small and medium-sized enterprises. 


\subsection{E-commerce and Cross-border E-commerce}

E-commerce is a business activity aimed at the exchange of goods through the network technology of computer information (Chen, 1998; Wu, 2017). E-commerce is an integration of network information technology and business activities, which can be divided into narrow and broad sense (Zhang, 2018). E-commerce in the narrow sense refers to transaction activities based on the Internet and other information technologies, that is, the buying and selling of products or services (Li, 2019). E-commerce in a broad sense refers to business activities based on network information technology that support the overall business process of enterprise production, supply, sales, personnel, and finance (Zeng, 2020).

Cross-border E-commerce is a type of E-commerce subject. It uses the Internet to conduct business trade activities, mainly cross-border trade transactions at home and abroad. The types of E-commerce transactions have also been diversified in recent years where B2B mode and C2C mode are more common (Zhou, 2017). Cross-border E-commerce also refers to a more advanced form of E-commerce application process. It means that both parties in different countries or regions pass customs through the Internet in the form of mail or express. The display, negotiation, and transaction links in trade are digitized, realizing a new trade method for product import and export (Qian et al., 2018).

In a narrow sense, Cross-border E-commerce refers to cross-border online retail, is an international business activity in which transaction entities belonging to various customs borders conduct transactions based on E-commerce platforms and cross-border payment settlement, with the help of cross-border logistics to transport products and realize transactions. From a broader perspective, Cross-border E-commerce refers to trans-border import and export business activities that belong to the transaction entities of each customs territory and conduct transactions based on E-commerce methods (Xu, 2019). It is currently a new form of international trade and is increasingly occupying a leading position in the development of international trade because of the global outstanding advantage in flexibility, paperlessness, and strong timeliness compared to traditional trade (Luo, 2020).

\subsection{The Impact of Cross-border E-commerce on the Apparel Industry}

With the rapid development of the Internet economy, the rapid development of Crossborder E-commerce has led to the increasing of the traditional real economy. While the popularity of clothing online sales continues to rise, and clothing has become hot-selling products in a cross-border online shopping (Cui, 2016; Guo, 2018; Li et al., 2020). Lei (2019) stated that Cross-border E-commerce is a product of the integration of economic globalization and E-commerce. Cross-border E-commerce in China's apparel industry has the characteristics of large proportion and rapid development in the overall Cross-border Ecommerce, and provides many challenges and opportunities to China's clothing industry.

The development speed of China's traditional apparel industry has slowed because of the fierce competitiveness (Chu, 2017), while B2C Cross-border E-commerce has shown a broad development space. Liu et al. (2019) also indicated that the development of the apparel retail industry in recent years was not optimistic. The traditional apparel retail industry was facing the challenge of transformation and upgrading. In the context of the Internet era, E-commerce has become the main economic model. As an indispensable commodity in daily life, clothing was favored by consumers at home and abroad. Crossborder trade was very suitable for apparel enterprises because of no restrictions on time and geographical area, and was relatively easier to manage and communicate. Xiu \& Bai (2016) suggested that for apparel export enterprises, the important role of Cross-border Ecommerce trade has become increasingly prominent. It has become the main way for Chinese apparel export enterprises to improve their brand's overseas image, explore 
international markets, and improve market competitiveness.

Cross-border E-commerce trade of apparel export enterprises was currently developing rapidly (Ding et al., 2020). With the help of a large amount of information technology industry content and the rapid development of E-commerce, it has formed a scale and create new profit growth points. Lv (2020) proposed that apparel industry has experienced more than 30 years of development since its establishment. It has a firm foundation and a complete production system in the apparel industry. With the development of E-commerce, the development of E-commerce in apparel industry was inevitable.

Zeng (2017) stated that the development of E-commerce for the international market can create fairer competition opportunities for apparel enterprises, and at the same time, the risks faced them will increase as a result. Faced with the development situation of Crossborder E-commerce, Chinese apparel enterprises must actively think about innovation and change in order to improve the development level of apparel enterprises and to enhance their competitiveness.

\section{The Background of SheIn Enterprise}

SheIn was a fashion wholesaling business founded in China and one of the leading online stores boasting high quality clothes and other fashionable accessories since 2008. The objective was to be the largest online wardrobe company around the world and to offer customers a variety of the latest and most fashionable clothing. It now boasted a presence in nearly every country in the world and made more than 20 billion yuan (US $\$ 2.83$ billion) in revenue in 2019. As of April 2020, SheIn covered more than 200 countries and regions around the world with a maximum daily shipment of more than 3 million pieces.

SheIn described itself as "an international B2C fast fashion E-commerce platform not only focuses on women's wear, but also offers men's apparel, children's clothes, accessories, shoes, bags and other fashion items" and it upheld the philosophy that "everyone can enjoy the beauty of fashion." SheIn provided the latest (almost daily) clothing in women's fashion from the high-streets of London, Paris, Tokyo, Shanghai \&New York at a favorable price. SheIn specialized in trendy women's clothes that were mostly priced below US\$20, with some items even selling for less than US\$5.

On April 2019, WPP cooperated with Google to release "Report on Top 50 Brands of Chinese Global Brand Builders 2019". The list was based on 400,000 consumer surveys from around the world, with samples concentrated in Europe, the United States, Japan, and Australia, showing foreign consumers' impressions of Chinese brands. In the list, Huawei, Lenovo, Alibaba, and other Chinese giant enterprises have made an excellent demonstration with their brand scores far exceeds other enterprises (Table 1). It was worth noting that SheIn, an obscure offshore clothing company in China, also ranked 14th with 496 points and a growth rate of $66 \%$. Among them, the online fast fashion industry was growing fastest, with SheIn and Zaful contributing 57\% of the industry's growth.

Compared with the international fast-fashion giant's preference for European, American, and Asia-Pacific markets, SheIn has captured the Middle East as an emerging market growth point. The penetration rate of Middle East market E-commerce was relatively low, the E-commerce population base was small, and the market was immature compared with Europe, American and other mature E-commerce markets. There were still many blind spots in the seller's selection, operation, layout and so on. Take selection as an example, the seller needed to stock up to the Middle East market with less information on suitable and best-selling products for reference. The uncertainty dominated and all the operating layout depended on learning-by-doing. 
Table 1. Report on Top 50 Brands of Chinese Global Brand Builders 2019

\begin{tabular}{ccccc}
\hline Rank & Brand Name & Type of Brand & Scores & $\begin{array}{c}\text { Growth } \\
\text { Rate }(\%)\end{array}$ \\
\hline 1 & HUAWEI & Consumer Electronics & 1,862 & $+22 \%$ \\
2 & Lenovo & Consumer Electronics & 1,698 & $0 \%$ \\
3 & Alibaba Group & E-commerce & 1,624 & $+48 \%$ \\
4 & MI & Consumer Electronics & 1,068 & $+41 \%$ \\
5 & ByteDance & Content APP & 878 & New \\
6 & Hisense & Appliances & 823 & $+55 \%$ \\
7 & Haier & Appliances & 776 & $+34 \%$ \\
8 & AIR CHINA & Aviation & 731 & $0 \%$ \\
9 & OnePlus & Consumer Electronics & 644 & $+38 \%$ \\
10 & ANKER & Consumer Electronics & 604 & $-1 \%$ \\
11 & FUNPLUS & Mobile Game & 577 & $+49 \%$ \\
12 & BANK OF CHINA & Banking & 523 & $+17 \%$ \\
13 & DJI & Intelligent Device & 496 & $-2 \%$ \\
14 & SheIn & Online Fast Fashion & 469 & $+66 \%$ \\
15 & CHINA EASTERN & Aviation & 450 & $+5 \%$ \\
\hline 48 & IM30 & Mobile Game & 143 & $-39 \%$ \\
49 & Midea & Appliances & 121 & $+7 \%$ \\
50 & HAINAN AIRLINES & Aviation & 121 & $-16 \%$ \\
\hline SO & & & \\
\hline
\end{tabular}

Sources: Foresight Industry Research Institute

Although the Middle East E-commerce market was still in its early stages, its growth rate was expecting. The "high unit price, low frequency" characteristics of the Middle East E-commerce market also made overseas investors hesitate. It said that the current average price per customer in the Middle East can reach US\$150, which was comparable with Europe and the US, especially for the regions of the United Arab Emirates and Saudi Arabia where the prices were even higher than the UK and the US. In addition, very few types of goods available in the Middle East E-commerce market resulted in lower online shopping frequency for local consumers.

SheIn has faced a rumpus in the domestic fast fashion market because of the increasing competitiveness of international giants and local fast fashion brands which suppressed its potential development space. However, the incomplete Middle East E-commerce market with "high growth rate, high unit price" characteristics demonstrated its market potential for investors that cannot be ignored. SheIn's early entry into the Middle East market and its focus on fast fashion segments enabled it to deliver better value for money by out-of-market returns. Policies benefits on the Cross-border E-commerce industry also helped to create a good market environment for the rapid grow of SheIn.

\section{Problems and Futures for the Cross-border E-commerce Development of SheIn}

SheIn was hardly known in China because they focused on foreign markets rather than domestic markets. Although SheIn has set up a Tmall flagship store in the domestic Ecommerce giant Taobao, only less than 20 pieces of new product were available and the number of fans was barely over 9,000. No monthly sales can reach 3 pieces, mostly zero, which made Tmall flagship store in vain. SheIn cannot even choose the Chinese and RMB payment on the APP, which showed it neglect to the domestic market although China's 
market potential was huge and the room for development was tremendous. Although SheIn has joined Amazon and sold products, there were many other well-known Cross-border Ecommerce platforms that can provide better opportunities.

SheIn's APP has crashed several times since 2020 due to a surge in orders. Their programmers have updated three or four versions in a week, indicating that there were many problems with the APP. In fact, their APP upgrade maintenance cannot keep up with growth in orders. The poor APP experience and usage directly also affected consumers' desire to buy although SheIn adopted a low-price strategy. The lower price strategy, however, reflected on the inadequate quality of the clothes.

Based on the above problems, this article proposed the following solutions:

\subsection{Pay Attention to China's Internal Market and Make Full Use of the Advantages of the Supply Chain and Geographic Location}

Compared with the logistics cost required by Cross-border E-commerce, the cost of domestic E-commerce logistics will be lower. With the continuous development of the domestic economy, the market for fast fashion clothing was also expanding. There was a well-developed E-commerce platform in China: Taobao, which can provide opportunities for SheIn to expand into the domestic market with feasible and beneficial development.

\subsection{Increase Technical Developers to Develop and Maintain APP}

As a Cross-border B2C clothing E-commerce platform, the user experience of APP was the foundation of its development. SheIn can speed up the training of the technical department and formed a group of professional and efficient technical personnel. Integration of different departments, such as marketing department and design department, can help technical department to avoid the lag of market awareness.

\subsection{Improve the Quality of Products within a Reasonable Cost and Build a Better Reputation}

Numerous suppliers and partners made SheIn difficult to control its quality. In fact, the number of orders has supported the development of many apparel factories and SheIn can take the advantageous position in the process of cooperation for quality requirements on the factories with guarantee contracts.

\subsection{Choose a Suitable Cross-border E-commerce Platform to Settle In}

Different countries and regions preferred diverse Cross-border E-commerce platforms. For example, Southeast Asia preferred Lazada and Shopee. The most popular Cross-border E-commerce platform in France was Cdiscount. In the United States, Amazon and eBay were very popular. Suitable platform can help enterprises to increase sales and SheIn should choose different platforms for further development.

\section{Conclusions and Recommendations}

The clothing industry was constantly developing through Cross-border E-commerce and has been developing steadily even during the COVID-19, especially in the fast fashion clothing industry. Among them, SheIn was a representative Cross-border fast fashion apparel enterprise either in terms of sales, financing, or product popularity.

SheIn currently owned 2 self-employed international sites (SHEIN and ROMWE), 9 small language sites, IOS mobile, Andriod mobile, and set up five customer service management centers around the world with more than 200 customer service team members that can quickly solve customers' problems of purchase process and after-sales process. 
Relying on its own strong IT technology strength, SheIn independently researched and developed business back-office IT support systems. Using the IT technology SheIn can improve business efficiency, combine with the characteristics of Cross-border E-commerce, and constantly optimize business processes to link all business seamlessly. Relying on stable quality, fast-updated style, good service, and innovative operation, SheIn's membership continued to grow and sales increased steadily toward a world-class fast fashion brand platform.

However, there were problems such as ignoring the domestic market, poor APP experience, and single sales platform along with its rapid development. The development of SheIn has brought inspiration to Chinese Cross-border E-commerce apparel enterprises on a complete supply chain that connected design, production, sales, logistics, and warehousing. A suitable target market for positioning, directing, and developing can help to accurately design and produce products that can satisfy target consumers.

\section{References}

1. Chen, Q. H. (1998). Interpretation of e-business. Finance and Accounting, 12, 3-5.

2. Chu, Z. (2017). Research on the development of B2C Cross-border E-commerce in the clothing Industry. Special Zone Economy, 11, 97-99.

3. Cui, X. M. (2016). Research on the impact of Cross-border E-commerce on clothing industry Export. Market Modernization, 23, 11-12.

4. Ding, H. T., Tang, Y. Q., Ding, X., Hao, Y. K., \& Zheng, Z. C. (2020). Problems and transformation strategies facing apparel export enterprises' Cross-border E-commerce trade. Textile Report, 1, 54-56.

5. Forward Business Information Co. (2020). Report of market prospective and investment strategy planning in China apparel retail market industry (2020-2025). Shenzhen: Forward Business Information Co.

6. Johnson, G., \& Scholes, K. (1999). Exploring corporate strategy: Texts and cases $\left(6^{\text {th }}\right.$ eds.), New York: McGraw Hill.

7. Lei, N. (2019). A review of research on Cross-border E-commerce in China's clothing industry. Knowledge Economy, 24, 88-89.

8. Li, L., Li, T., \& Guo, C. R. (2020). Research on the transition and development of Cross-border E-commerce strategies of clothing foreign trade enterprises-Taking Ningbo as an example. Foreign Trade, 4, 58-60.

9. Li, L. (2013). Research on inventory management of garment enterprises in supply chain environment. Business, 16, 36-36.

10. Li, Z. R. (2019). Research on application of computer technology in electronic commerce system. National Circulation Economy, 2, 28-29.

11. Liu, H. L., Wang, X. S., \& Xu, D. (2019). Research on the functions and services of clothing retail terminals in the new retail mode. Logistics Technology, 42(8), 53-56.

12. Luo, R. (2020). Opportunities and challenges faced by international trade under the background of E-commerce. Chinese Business, 3, 114-115.

13. Lv, X. Y. (2020). Research on Cross-border E-commerce of clothing industry in Humen Town. E-commerce, 3, 24-25.

14. Guo, Y. (2018). Countermeasures for the export transformation and development of garment enterprises under the background of Cross-border E-commerce. Enterprise Technology and Development, 8, 35-37.

15. Qian, P., Xu, D. M., \& Zhang, S. (2018). Cross-border E-commerce-A new employment choice for foreign language graduates. Journal of Qingdao University, 31(S1), 86-89. 
16. Wu, H. (2017). The role of computer technology in E-commerce network consumption interaction. Electronic Production, 8, 46-47.

17. Xiu, L. Y., \& Bai, L. L. (2016). Problems and transformation strategies facing apparel export enterprises' Cross-border E-commerce Trade. Financial Economy, 24, 123-124.

18. Xu, Y. S. (2019). Analysis on the problems and countermeasures of Cross-border Ecommerce talent training in universities. Education Modernization, 6(92), 1-3.

19. Zeng, H. (2017). Discussion on measures for clothing foreign trade enterprises to implement Cross-border E-commerce. Guangdong Sericulture.

20. Zeng, Y. M. (2020). Research on the development strategy of international economy and trade under the background of E-commerce. Economic Outlook of Bohai Sea, 1, 20.

21. Zhang, S. D. (2018). Research on cost management of E-commerce enterprises in China. Rural Economy and Technology, 29(21), 157-158.

22. Zhou, S. (2017). Transition and development of Cross-border E-commerce in the era of free trade zone. Technology Economy Market, 4, 106-107.

(Editors: Yan, Jia-Yi \& Li, De-Lan) 